\title{
Identification and Expression Analysis of Wheat Vacuolar Processing Enzymes (VPEs)
}

\author{
Tae Hoon Kang, Dae Yeon Kim, and Yong Weon Seo* \\ College of Life Science and Biotechnology, Korea University, Anam-dong, Seongbuk-gu, Seoul 136-713, Korea
}

\begin{abstract}
Vacuolar proteins are associated with various functions, such as germination and programmed cell death (PCD) activity. Precursors of most vacuolar proteins are synthesized in the rough endoplasmic reticulum (rough ER). They are transported to the vacuoles, and converted into the mature forms. Vacuolar processing enzyme (VPE) is responsible for maturation of vacuolar proteins. Intensive studies revealed that VPE-mediated system is important for vacuolar functions in plant. However, the role and mechanism of VPE still remain to be elucidated, especially in wheat. Here, we isolated three putative wheat VPE genes which were designated as TaVPE2, 3 and 4. To investigate the expression of TaVPEs, RT-PCR was conducted using RNAs extracted from caryopsis, pericarp, leaf and/or stem tissues at seed development stage and leaf, stem and/or root of seedling with phytohormone or abiotic stress treatment. Transcript accumulation of TaVPEs including TaVPE1 was displayed in caryopsis during seed development stage. TaVPE1, TaVPE2 and TaVPE3 were expressed in root under abiotic stress whereas they showed no or very weak expression pattern in other tissue. Promoter region of TaVPEs contain many environmental-associated and tissue-specific cis-elements. In fact, VPEs sensitively responded to certain treatment condition. TaVPEs belong to seed type VPE in phylogenetic grouping. However, expression pattern of TaVPEs is different from other seed type VPEs. The classification into vegetative and seed type VPE according to gene expression patterns cannot be applied to TaVPEs.
\end{abstract}

Keywords Vacuolar processing enzyme, Wheat, Promoter analysis, Grain development

\section{INTRODUCTION}

The vacuole is an enclosed compartment that is widely distributed in most plant organisms. Particularly, vacuole is well developed in higher plants compared with other organism. The central vacuole in plant cells performs diverse functions such as waste storage, tugor pressure maintenance, protein storage, and balancing between biogenesis and degradation. It was examined that plant cells contain two functionally distinct vacuolar compartments, lytic vacuole and protein storage vacuole (Bethke et al. 1996). A lytic vacuole maintained at an acidic $\mathrm{pH}$ and contains degradative enzymes, including a wide variety of acid hydrolases. A protein storage vacuole functions primarily in the storage of materials, including nutrients, pigments, waste products, and small molecules.

Vacuolar proteins are associated with various functions, such as germination, senescence and hypersensitive response (HR). Precursors of most vacuole-related proteins are synthesized in the rough endoplasmic reticulum (rough ER) in higher plants. They are transported to the vacuoles, and converted into the respective mature forms (HaraNishimura et al. 1985; Hara-Nishimura and Nishimura 1987). Vacuolar processing enzyme (VPE, also called vacuolar protease or $\mathrm{C} 13$ peptidase) is isolated in maturing castor bean seed and is characterized that it is associated with maturation and activation of seed storage proteins (Hara-Nishimura et al. 1991). After that, many intensive studies revealed that VPE is widely existed in plant, such as soybean (Shimada et al. 1994), vetch (Becker et al. 1995), citrus (Alonso and Granell 1995), tobacco (Zakharov and Muntz 2004) and Arabidopsis (Kinoshita et al. 1995a; Kinoshita et al. 1995b). Research of cereal crop VPE displayed that VPEs were detected in rice (Wang et al.

Received Jun 16, 2013; Revised Jun 22, 2013; Accepted Jun 23, 2013; Published June 30, 2013

*Corresponding author Yong Weon Seo, seoag@korea.ac.kr, Tel: +82-2-3290-3464, Fax: +82-2-3290-3501

Tae Hoon Kang and Dae Yeon Kim contributed equally to this work. 
2009) and barley (Linnestad et al. 1998). These VPEs belong to a novel family of cysteine protease. Legumains are a new family of cysteine protease in tobacco. Due to their vacuolar localization and processing function, legumains have been also named VPE (Zakharov and Muntz 2004). VPEs are synthesized as precursors that are self-catalytically converted into the mature forms. The self-catalytic activation was found with Arabidopsis VPE. It was expressed in the insect cell and occurred under acidic condition (Kuroyanagi et al. 2002).

Seed storage proteins are accumulated in protein storage vacuoles. It provides a nitrogen source for seedling growth during early stage of germination (Müntz 1998). VPEs perform unique functions in seed storage protein processing. Intensive studies revealed that a mechanism for VPEmediated maturation of seed storage proteins was proved in Arabidopsis knock-out mutant series (Gruis et al. 2004). In the analysis of VPEs activity in dry seed of Arabidopsis, $\beta$ VPE knockout mutants did not have matured seed storage proteins but precursors of seed storage proteins. Programmed cell death (PCD) is a basic physiological process under various stressed conditions and development of higher organisms including plant (Vaux and Korsmeyer 1999). Apoptosis, a representative type of PCD, occurs in the immune system under various stressed condition and development stage of organism. However, plant defense mechanism is so different from animal defense mechanism because plants have no immune system unlike animals. Many intensive studies carried out to explain ambiguous mechanism and characterization of plant PCD mechanism and it is revealed that PCD in plant and animals shares components that include caspase-like activity (Cohen 1997; Woltering et al. 2002; Bonneau et al. 2008). Recently, VPE has been displayed to be a protease that exhibits caspase-1-like activity. For example, VPE is responsible for tobacco mosaic virus (TMV) induced hypersensitive cell death in tobacco leaves (Hatsugai et al. 2004). In case of Arabidopsis, $\delta \mathrm{VPE}$ is highly expressed in two cell layers of the inner integument of the seed coat during early stage in embryogenesis. $\delta \mathrm{VPE}$ has shown that PCD occurs not only under disease or stressed conditions but also during plant development including seed coat formation (Nakaune et al. 2005). As undergoing senescence or stress, the excreted endogenous hormone is changed and many genes are ready to activate. Arabidopsis VPE is activated by senescence or stressed condition (Kinoshita et al. 1999). Wheat vacuolar protease was up-regulated in senescing leaf induced by different factors (Martinez et al. 2007).

With the aid of completed Arabidopsis genome sequencing, four subfamilies of VPEs in Arabidopsis ( $\alpha, \beta, \gamma$, and $\delta$ VPE), were isolated and well characterized (Kinoshita et al. 1995a; Kinoshita et al. 1995b; Nakaune et al. 2005). Many roles of VPE, such as seed storage protein maturation, apoptosis mediation and developmental cell death mediation have been examined by Arabidopsis (Hara-Nishimura et al. 2005; Yamada et al. 2005).

Despite of functional importance of VPE in plants, wheat cysteine proteases including VPE have not been intensively studied at gene level (Kiyosaki et al. 2009). Recently, using a map-based cloning strategy, we isolated three VPE genes of wheat (TaVPEs) from cDNA library of wheat spikelet at DAF16 and DAF18. The isolated three putative VPE wheat subfamily genes, TaVPE2, 3 and 4 are homologs of wheat VPE1 that is deposited in the GenBank database. Here, we report temporal and spatial expression patterns of TaVPEs in tissues of wheat such as spikelet and seedling. We also discuss promoter region analysis and expression of the VPE genes under various stress conditions and exogenous phytohormone treatments.

\section{MATERIALS AND METHODS}

\section{Isolation of TaVPE subfamilies of wheat}

We constructed cDNA library to isolate genes expressed during seed development stage. Total RNA of infested seedling was extracted from spikes at 16 and 18 DAF (days after fertilization) using Trizol according to commercial protocols (Gibco/BRL, USA.). Poly(A) ${ }^{+}$RNA was isolated with the PolyATRact mRNA isolation system (Promega, USA). A cDNA library was constructed using Uni-ZAP XR vector (Stratagene, USA.). The phage library was excised to pBluescript plasmids as described by the manufacturer (Stratagene). The obtained phages of the library were transformed into Escherichia coli strain SOLR. Plasmid DNAs were isolated from the randomly selected 
clones, and 74 clones were successfully sequenced. The K59 clone that showed highly homology to sequence of TaVPE1 (Triticum aestivum vacuolar processing enzyme 1, access no. EF682132) was used in this study. Additionally, we collected 74 expressed sequence tag (EST) sequences to isolate TaVPE family genes using the term "vacuolar processing enzyme" in NCBI. ClustalW at the European Bioinformatics Institute (EBI) was used (http://www.ebi.

Table 1. List of primer sequences and their purposes.

\begin{tabular}{|c|c|c|c|}
\hline Name & Forward (5' to $\left.3^{\prime}\right)$ & Reverse (3' to 5') & Purpose \\
\hline TaVPE1 & GATGAACTCGAGGGTGGCGATGGC & TCAGGCGCTG TAGCCTCGAA CCAGC & $\begin{array}{l}\text { Isolation of } \\
T a V P E 1 \mathrm{cDNA}\end{array}$ \\
\hline TaVPE1 RT & TTTTACCTGTTTAGGTGACTT & TCGGAGACGCCATTGTTGCAC & $\begin{array}{l}\text { Analysis of } \\
\text { TaVPE1 expression }\end{array}$ \\
\hline TaVPE1 UP1 & & CCGTTGGGCATACCAAGTGAACCAGGAGA & $\begin{array}{l}\text { Isolation of the } \\
\text { TaVPE1 promoter }\end{array}$ \\
\hline TaVPE1 UP2 & & AGCGGGAGGAGTCCACAAACCCACCACG & $\begin{array}{l}\text { Isolation of the } \\
\text { TaVPE1 promoter }\end{array}$ \\
\hline TaVPE2 & GGCTCTAGCACACGCACATGAAC & GAGCATTTGGTACTGCTCCCATGTA & $\begin{array}{l}\text { Isolation of } \\
\text { TaVPE2 } 2 \text { cDNA }\end{array}$ \\
\hline TaVPE2 RT & TGCCGTTTGTTTATGCTGGCGAC & AAACGCTGCCTGAAATAACTGGA & $\begin{array}{l}\text { Analysis of } \\
\text { TaVPE2expression }\end{array}$ \\
\hline TaVPE2 UP1 & & CACCGCCAGCAGCAGAAGCGGGAGGAGT & $\begin{array}{l}\text { Isolation of the } \\
T a V P E 2 \text { promoter }\end{array}$ \\
\hline TaVPE2 UP2 & & AGCGGGAGGAGTCCACAAACCCACCACG & $\begin{array}{l}\text { Isolation of the } \\
\text { TaVPE2 promoter }\end{array}$ \\
\hline TaVPE2 UP3 & & TATGCGCTTCTGCGCTGCAGCTGAAAA & $\begin{array}{l}\text { Isolation of the } \\
\text { TaVPE2 promoter }\end{array}$ \\
\hline TaVPE UP4 & & GAAGGACTCAGCTTAGTCCAGATCCTT & $\begin{array}{l}\text { Isolation of the } \\
\text { TaVPE2 promoter }\end{array}$ \\
\hline TaVPE3 IPCR1 & TTGCAAACATGTGCAACAATGGCATC & CAATGTTCTCCTCCTTTAGGCCCCC & $\begin{array}{l}\text { Isolation of } \\
\text { TaVPE3 cDNA }\end{array}$ \\
\hline TaVPE3 IPCR2 & CGAAATGAGGGAAGCAAGCATCAG & CTTCCTCAGGATCTGGTAGGCGTG & $\begin{array}{l}\text { Isolation of } \\
\text { TaVPE3 cDNA }\end{array}$ \\
\hline TaVPE3 RT & TGCCGTTTGTTTATGCTGGCGAC & AACCTATACTGGACTCATTTC & $\begin{array}{l}\text { Analysis of } \\
\text { TaVPE3 expression }\end{array}$ \\
\hline TaVPE31 UP1 & & TTTTTCAGGATCTGGTACGCGTGGCACACA & $\begin{array}{l}\text { Isolation of the } \\
\text { TaVPE2 promoter }\end{array}$ \\
\hline TaVPE3 UP2 & & AGCGGGAGGAGTCCACAAACCCACCACG & $\begin{array}{l}\text { Isolation of the } \\
\text { TaVPE2 promoter }\end{array}$ \\
\hline TaVPE4 IPCR1 & CATGAGGGCGTTCGCCAACATATGCAAC & CAGCAGAAGCGGGAGGAGTCCACAAAC & $\begin{array}{l}\text { Isolation of } \\
\text { TaVPE4 cDNA }\end{array}$ \\
\hline TaVPE4 IPCR2 & AAGCATCAGGGCCTGCGACGATTAC & AGAAGCGGGAGGAGTCCACAAACCCAG & $\begin{array}{l}\text { Isolation of } \\
\text { TaVPE4 cDNA }\end{array}$ \\
\hline TaVPE4 RT & TGATATCGCCAAAAACGACCTC & GAACCCTTATCGAATTCCTTTGA & $\begin{array}{l}\text { Analysis of } \\
\text { TaVPE4 expression }\end{array}$ \\
\hline TaVPE41 UP1 & & TCCAGTAACCGCGGTTTTGTTCCCCAAT & $\begin{array}{l}\text { Isolation of the } \\
\text { TaVPE4 promoter }\end{array}$ \\
\hline TaVPE4 UP2 & & CCGCCAGGAACGGGAGGAATCCACAA & $\begin{array}{l}\text { Isolation of the } \\
\text { TaVPE4 promoter }\end{array}$ \\
\hline Ta Actin & GCCACACTGTTCCAATCTATGA & TGAAATTGTATGTCGCTTC & $\begin{array}{l}\text { Analysis of } \\
\text { TaVPEs expression }\end{array}$ \\
\hline
\end{tabular}


ac.uk/clustalw/) to perform multiple alignments of the EST sequences. Two pairs of forward and reverse primers of TaVPE 2 gene were designed from the sequences of the putative $5^{\prime}$ and $3^{\prime}$ untranslated regions (UTRs) by comparison with the EST sequences. PCR was performed using specific primers for TaVPE1 and TaVPE2. The PCR cycling conditions consisted of 31 cycles of $94^{\circ} \mathrm{C}$ for $60 \mathrm{~s}, 58^{\circ} \mathrm{C}$ for $60 \mathrm{~s}$, and $72^{\circ} \mathrm{C}$ for $60 \mathrm{~s}$. In addition, Inverse polymerase chain reaction (IPCR) was conducted to isolate TaVPE3 and TaVPE4 based on the EST sequence from NCBI according to protocol of Sambrook and Russell (2006). Briefly, genomic DNA $(1.5 \mu \mathrm{g})$ was digested with $15 \mathrm{U}$ of EcoRI and HindIII for $2 \mathrm{~h}$. The digested DNA was dissolved in $0.1-0.2 \mu \mathrm{g} / \mathrm{ml}$ distilled water followed by phenol/chloroform extraction and ethanol precipitation. The fragments were self-ligated into circular DNA in a mixture containing $10 \mu \mathrm{l}$ of isolated fragments, $3 \mu \mathrm{l}$ of $10 \times$ ligation buffer (TaKaRa), $3 \mathrm{U}(1 \mu \mathrm{l})$ of T4 DNA ligase, and $16 \mu \mathrm{l}$ of distilled water at $16^{\circ} \mathrm{C}$ for $16 \mathrm{~h}$. The IPCR cycling conditions for TaVPE3 and TaVPE4 consisted of 35 cycles of $94^{\circ} \mathrm{C}$ for $60 \mathrm{~s}, 60^{\circ} \mathrm{C}$ for $60 \mathrm{~s}$, and $72^{\circ} \mathrm{C}$ for $60 \mathrm{~s}$, with a final cycle of $10 \mathrm{~min}$ at $72^{\circ} \mathrm{C}$. The sequence of all primers used in this study is shown in Table 1. Amplification products were cloned into the T\&A cloning vector and sequenced.

\section{Plant materials}

Seeds of Korean common wheat (Triticum aestivum L. cv. Geumgangmill) were germinated on moistened filter paper as described by Lee et al (2007). For a synchronized germination pattern, seeds with moistened filter paper were stored in a refrigerator at $4^{\circ} \mathrm{C}$. After 36 hours, 16 imbibed seeds were transferred to a container $(6.5 \times 6.5 \times 20 \mathrm{~cm})$ containing a polypro-mesh and supported by acryl struts. Seedlings were positioned on the polypro-mesh into a solution of $200 \mathrm{ml}$ of distilled water. Seedlings were grown in a growth chamber (Vision scientific, Korea) set at a photo-cycle of $13 / 11 \mathrm{~h}$ (day/night) $22 / 18^{\circ} \mathrm{C}$ (day/night) and exposed to light (10,000 lux) during day portion of the cycle. The water in the container was replaced with distilled water once a day. After 5 days of imbibitions, plants were transferred to $200 \mathrm{ml}$ in half-strength of Hoagland's nutrient solution, until further treatments. Control plants were prepared and grown under same environmental conditions.

For the study at seed development stage, seeds of wheat (Triticum aestivum L.) cv. Geumgangmill were planted in the field (Deokso, Namyangju, republic of Korea). The field was managed under standard agricultural practices, and received non-limiting rainfall during the growing season. Individual spike was tagged $1 \mathrm{DAF}$, as judged by the 3/4-projection of the awns from the leaf sheath. These spikes were tagged at 1, 5, 10, 15, 22, 30, 40 DAF and selected in main stem. Caryopsis and pericarp were embedded in tube with RNAlater solution (Ambion, USA). Leaf and stem were frozen immediately in liquid nitrogen. Then samples pre-mixed with RNAlater solution were plunged in liquid nitrogen and stored at $-80^{\circ} \mathrm{C}$.

\section{Abiotic stress treatment, phytohormone application and tissue sampling}

The seedlings at 13 days after germination (secondary leaf was fully-expanded) were transferred to $200 \mathrm{ml}$ of halfstrength of Hoagland's nutrient solution, which contains 5 $\mathrm{mM}$ of salicylic acid (SA), $100 \mu \mathrm{M}$ of gibberellic acid (GA3) and $100 \mu \mathrm{M}$ of abscisic acid (ABA). In order to examine the responses of the TaVPE genes to abiotic stress, seedlings were treated via dissolving root parts in $200 \mathrm{ml}$ of half-strength of Hoagland's nutrient solution dissolved with each of polyethylene glycol (PEG, 25\%, MW 10,000), $\mathrm{NaCl}(250 \mathrm{mM})$ and $\mathrm{H}_{2} \mathrm{O}_{2}(100 \mathrm{mM})$. The solution in the each container was replaced with fresh solution once a day. Leaf, stem and root tissues of samples were collected at 0 , $6,12,24,48$ hours after each treatment. Samples were immediately frozen in liquid nitrogen and stored at $-80^{\circ} \mathrm{C}$ in deep freezer until further usage. Plant tissues including caryopsis, pericarps, stems and leaves were collected in the field at scheduled days (DAF 1, 3, 5, 8, 10, 12, 15, 17, 19, $22,25,30,35$ and 40 ). All samples were frozen immediately in liquid nitrogen, and then stored at $-80^{\circ} \mathrm{C}$.

\section{RNA extraction and RT-PCR analysis}

Total RNA was extracted from individual tissues with TRIzol reagent (Molecular Research Center, Inc). RNA extraction was conducted according to the manufacturer's instructions. The extracted RNA from each tissue was utilized as a template for first-strand cDNA synthesis using 
a first-strand cDNA synthesis Kit (iNtRON Biotechnology, Korea). First-strand cDNA synthesis was performed at 4 $2{ }^{\circ} \mathrm{C}$ for $60 \mathrm{~min}$ and terminated by enzyme inactivating reaction at $70^{\circ} \mathrm{C}$ for $5 \mathrm{~min}$. For Semi-quantitative RT-PCR analysis, gene-specific primers were designed by cDNA sequence alignment of TaVPE genes (Table. 1). The RTPCR products were cloned and sequenced to confirm the target gene specificity of each gene-specific primer. TaVPE2 and TaVPE3 share 5' gene specific primer because of high homology between TaVPE2 and TaVPE3. The actin primers were designed from Taactin sequence at the GenBank and served as an internal control. RT-PCR experiments were processed in a thermo-cycler (MJ research, USA) and PCR conditions of the RT-PCR are listed in Table 1. The RT-PCR products were analyzed by $1 \%$ agarose gel electrophoresis in $1 \mathrm{X}$ TAE buffer and stained with ethidium bromide (EtBr).

\section{Promoter analysis of TaVPEs}

Genomic DNA was isolated from the leaf tissues of common wheat cv. "Geumgangmill". In order to isolate promoter region of the TaVPE genes, we used the universal GenomeWalker kit (Clonetech). The genomic DNA was digested with five blunt end-forming restriction enzyme (PvuII, EcoRV, StuI, SmaI, DraI). After digestion, GenomeWalker adaptor was ligated with digested genomic DNA. After adapter primer annealed digested genomic DNA with gene-specific primer, PCR was conducted. The gene-specific primers used are shown in Table 1. The PCR product was cloned into RBC vector and sequenced. Because of high similarity among TaVPEs, one genespecific primer was applied to PCR VPE1, 2 and 3. After sequence conformation, secondary PCR was conducted because primary PCR products have insufficient nucleotide length for promoter analysis. Gene specific primer of secondary PCR was made from promoter region of TaVPE. PCR was processed according to the manufacturer's instructions (The Universal Genome Walker Kit, Clonetech). The search for cis-acting elements on the promoter region of TaVPE genes was performed using plantCARE (Lescot et al. 2002) and PLACE Web Signal Scan (Higo et al. 1999). The correlation between the cis-acting elements and expression pattern was analyzed for each TaVPE gene.

\section{RESULTS}

\section{Sequence comparison of the VPE genes of wheat and other plants}

We constructed cDNA library to isolate genes expressed during seed development stage. About 69, out of 180 clones, showed a significant degree of homology to sequence registered in the National Center for Biotechnological Information (NCBI) (Appendix Table 1). The K59 clone that showed highl homology to partial sequence of TaVPE1 (Triticum aestivum vacuolar processing enzyme 1, access no. EF682132) was used in this study. The isolated cDNAs encoding TaVPE1, 2, 3 and 4 contained 1,482, $1,482,1,482$ and $1,467 \mathrm{bp}$ open reading frames and encoded 493, 493, 493 and 488 amino acids, respectively. Nucleotide sequence similarities among TaVPEs ranged from $84 \%$ to $93 \%$. The N-terminal of all deduced TaVPE sequences was analyzed using the SignalIP program (http:// www.cbs.dtu.dk/services/SignalP). All deduced TaVPEs did not contain any potential cleavage site. Predicted isoelectric points of TaVPEs ranged from 6.80 to 6.94, and molecular weights were from 54.07 to $54.5 \mathrm{kDa}$. Characteristics of cDNAs, predicted proteins and similarities

Table 2. Characteristics of TaVPEs cDNAs and proteins from Triticum aestivum cv. Geumgangmill.

\begin{tabular}{|c|c|c|c|c|c|c|c|c|c|c|}
\hline \multirow{3}{*}{ Gene } & \multicolumn{4}{|c|}{ cDNA } & \multicolumn{6}{|c|}{ Mature Protein } \\
\hline & \multirow{2}{*}{ Length } & \multicolumn{3}{|c|}{ Identity (\%) } & \multirow{2}{*}{ Length } & \multirow{2}{*}{$\mathrm{kDa}$} & \multirow{2}{*}{$\mathrm{pI}$} & \multicolumn{3}{|c|}{ Identity (\%) } \\
\hline & & TaVPE1 & TaVPE2 & TaVPE3 & & & & TaVPE1 & TaVPE2 & TaVPE3 \\
\hline TaVPE1 & 1482 & & & & 493 & 54.4 & 6.8 & & & \\
\hline TaVPE2 & 1482 & 89 & & & 493 & 54.35 & 6.84 & 86 & & \\
\hline TaVPE3 & 1482 & 92 & 93 & & 493 & 54.5 & 6.8 & 90 & 92 & \\
\hline TaVPE4 & 1467 & 85 & 85 & 85 & 488 & 54.07 & 6.94 & 79 & 79 & 81 \\
\hline
\end{tabular}


were summarized in Table 2.

The four TaVPE genes were closely related from the peptide comparisons (Fig. 1). Amino acid sequence homologies among TaVPEs ranged from $79 \%$ to $92 \%$. TaVPE2 and TaVPE3 showed most close relationship with $92 \%$ sequence similarity, while relatively lower similarities were observed between TaVPE4 and other TaVPE genes.
To find a significant consensus pattern, we analyzed the TaVPE1, 2, 3 and 4 proteins with ExPAsy Proteomic Sever System (www.expasy.org/prosite). We also added the amino acid sequence of Rice NP1 (AAL40390) and barley NP1 (AAD04882). Rice NP1 and barley NP1 showed higher homologies to wheat than amino acid sequences of other plants VPE. Additionally, these two VPE genes were

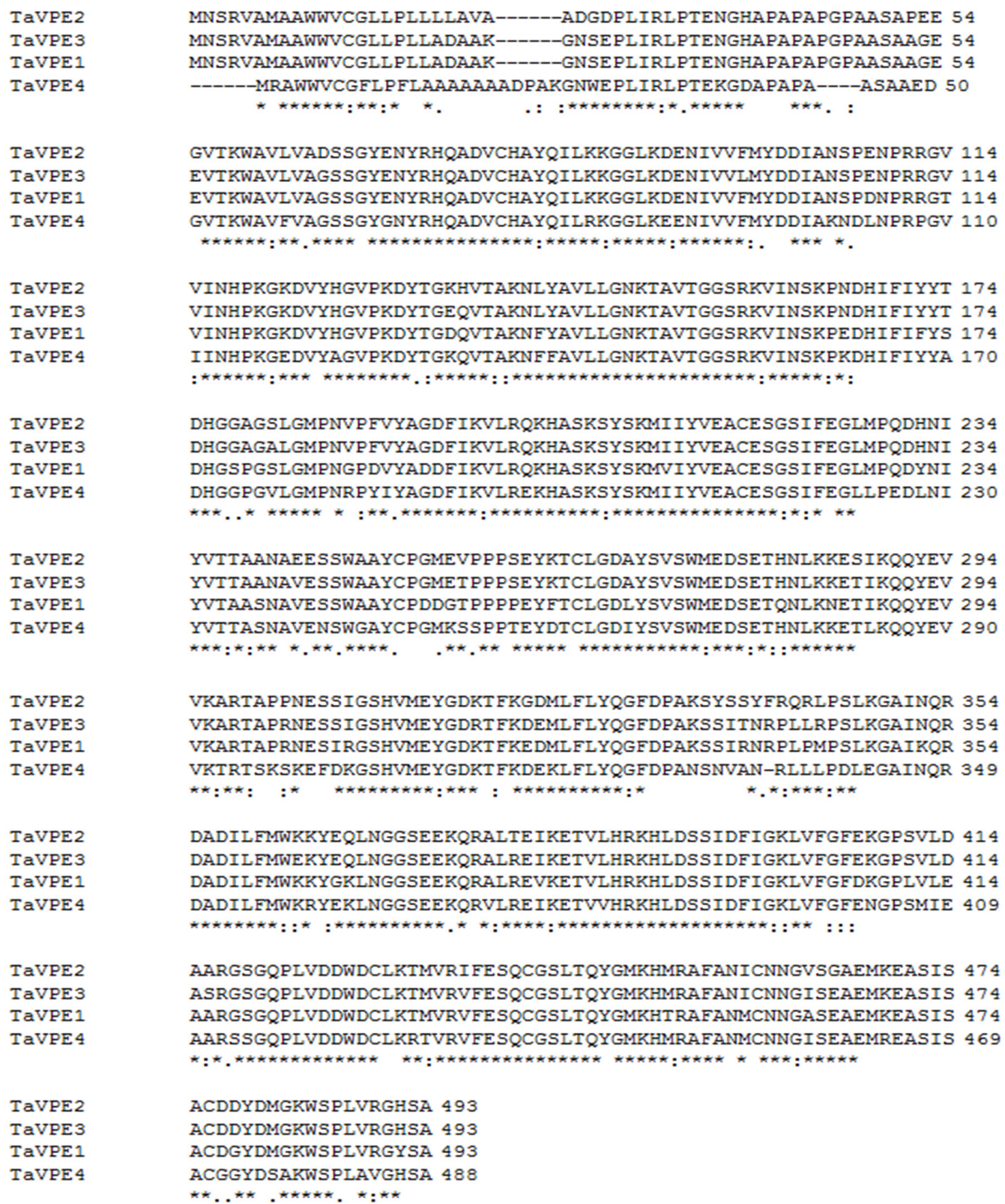

Fig. 1. Comparison chart of amino acid sequence of the TaVPE genes. The numbers at the end of right side in each line were the cumulative total number of amino acids sequence in each line. "*"indicated the same 4 amino acid sequence at that position among all amino acid sequence. ":" indicated the same 3 amino acid sequence and "." the same 2 amino acid sequence. 


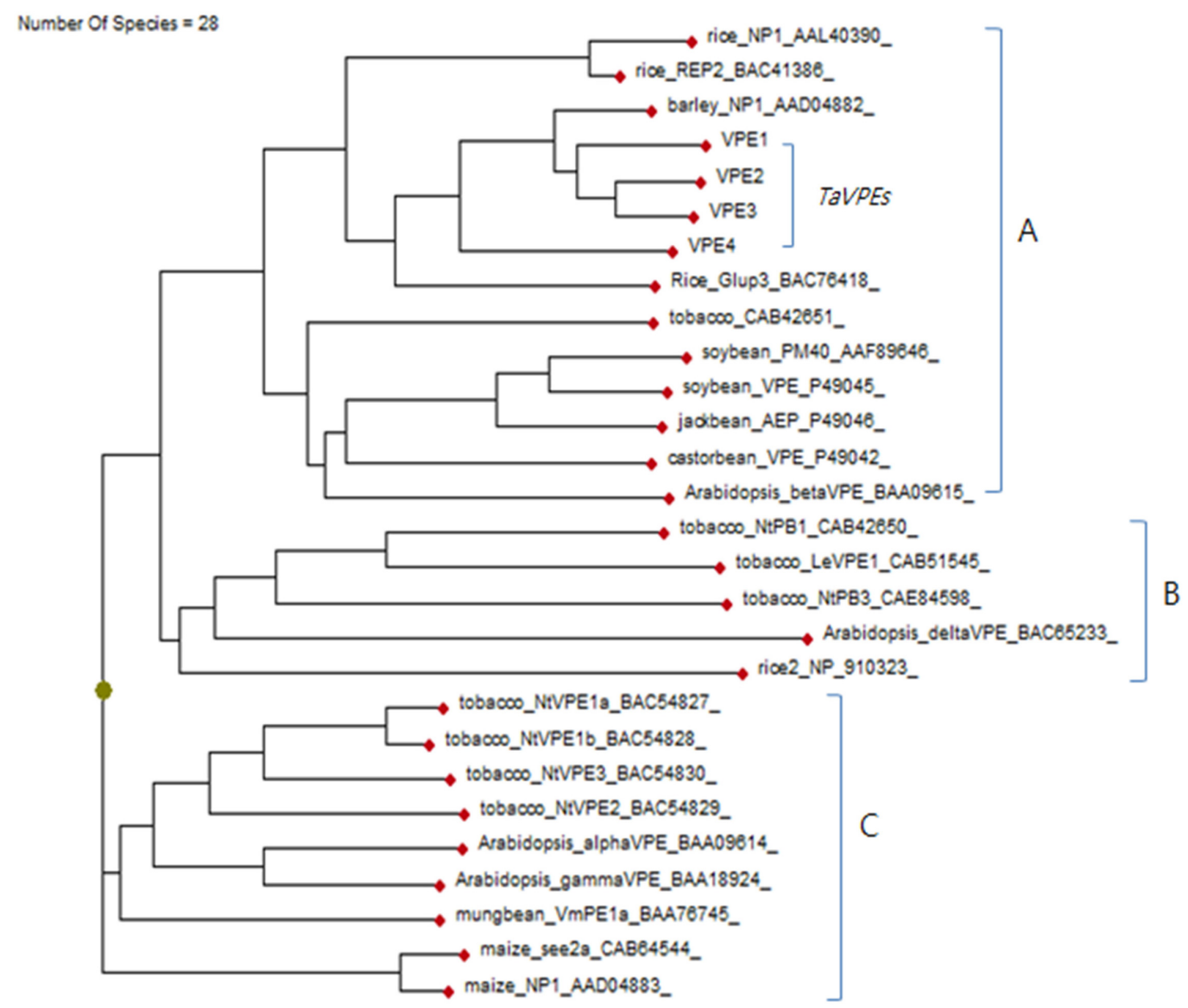

Fig. 2. Phylogram of the relationship between TaVPE family and other plant VPE proteins. VPE can be separated into three types that are seed (A), novel (B, also called uncharacterized) and vegetative types (C).

isolated from major cereal crops (Linnestad et al. 1998).

VPE genes had 4 conserved domain, casein kinase II phosphorylation site, N-myristoylation site, N-glycosylation site and protein kinase $\mathrm{C}$ phosphorylation site. In barley NP1, we observed absence of Cyclic adenosine 5'-monophosphate (cAMP)- and cyclic guanosine 5'-monophosphate (cGMP)- dependent protein kinase phosphorylation site whereas other VPEs possessed this domain. Otherwise, rice NP1 contained additional domain, Tyrosine kinase phosphorylation site. TaVPE1, 2, 3 and 4 contains a conserved vacuolar processing enzyme domain (http://www. ebi. ac.uk/Tools/InterProScan).

A phylogram for the phylogenetic relationship of the TaVPEs and other plant TaVPEs were constructed (Fig. 2). The 24 protein sequences except for TaVPE were obtained in NCBI.

\section{Developmental and tissue-specific expression of TaVPE genes}

To investigate the seed developmental expression of TaVPE genes, RT-PCR was carried out with RNAs isolated from leaf, stem, pericarp and caryopsis at different development stages. The amplified RT-PCR products were 610 bp (TaVPE1), 472 bp (TaVPE2), 365 bp (TaVPE3) and $678 \mathrm{bp}$ (TaVPE4) in length. Each TaVPE gene exhibited different expression pattern (Fig. 3). Expression of TaVPE1 increased gradually until $40 \mathrm{DAF}$ in caryopsis. No signal of TaVPE1 was detected in stem and pericarp. Otherwise, transcripts of TaVPE1 were detected at $35 \mathrm{DAF}$ whereas TaVPE1 was not observed until 25 DAF in leaf. TaVPE2 was expressed during seed development in caryopsis. However, accumulation of TaVPE2 transcripts was not detected in vegetative tissues. In caryopsis, TaVPE3 expression was found at $5 \mathrm{DAF}$, reached a peak at $10 \mathrm{DAF}$ 

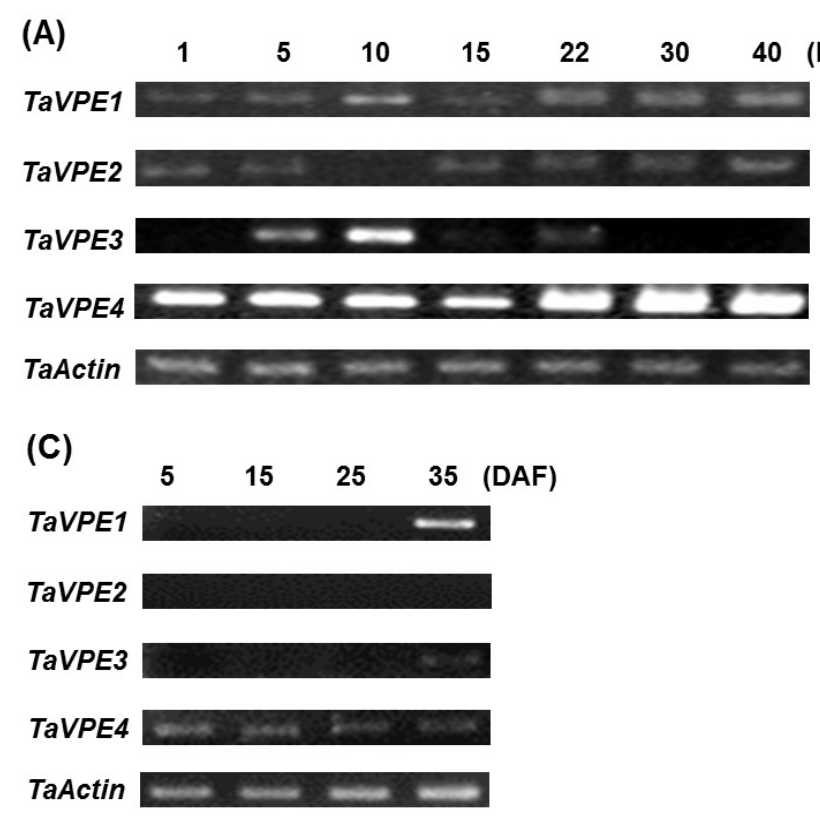
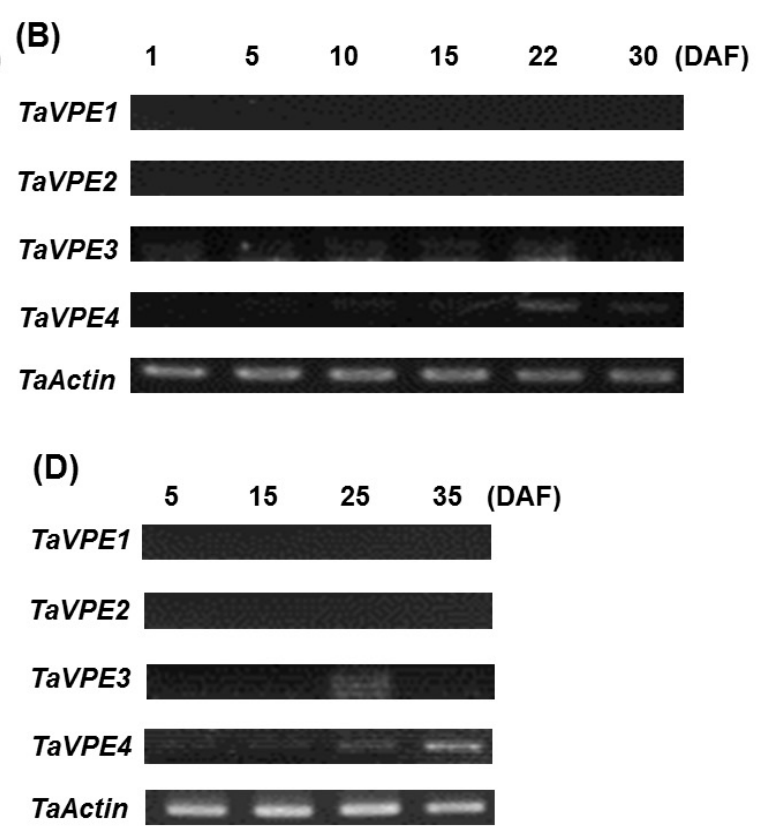

Fig. 3. Transcripts accumulation of the TaVPEs in different tissue during seed development stage. (A) caryopsis, (B) pericarp, (C) leaf, and (D) stem. DAF: days after fertilization.

and decreased until $22 \mathrm{DAF}$. After $30 \mathrm{DAF}$, transcripts of TaVPE3 were not detected. TaVPE3 was not expressed in vegetative tissues, but its transcript was detected in senescence leaf. TaVPE4 was expressed in all tissues during seed development stage. However, expression pattern of TaVPE4 is different in each tissue. Signal strength of TaVPE4 was similar during DAF in leaf. However, TaVPE4 expression was increased gradually in other tissues. Transcription level of TaVPE4 was especially high compared with other expression pattern.

\section{Expression of TaVPE genes in response to exogenous hormones and abiotic stress treatments}

Semi-quantitative RT-PCR was used to investigate the accumulation of TaVPE transcripts in response to exogenous hormones and abiotic stress treatments. Expression analysis of TaVPE genes displayed various transcripts accumulation pattern, compared to the non- treated samples (Fig. 4, Fig. 5). TaVPE1 was not expressed in PEG, $\mathrm{ABA}$ and $\mathrm{GA}_{3}$ treatment. In leaf tissue, accumulation of TaVPE1 was slightly increased under $\mathrm{NaCl}$ treated condition. On the other hand, TaVPE1 was expressed in root under both of $\mathrm{NaCl}$ and $\mathrm{H}_{2} \mathrm{O}_{2}$ treated condition and gradually decreased after treatment. TaVPE1 was more significantly expressed in root than in leaf. Unlike, TaVPE1, transcripts of TaVPE2 were not present under most treated conditions. Only TaVPE2 expression was slightly increased after PEG treatment and was detected slightly in root during $\mathrm{H}_{2} \mathrm{O}_{2}$ treatment. Expression of TaVPE2 was not observed in stem. A weak expression of TaVPE3 is detected in the roots. In case of stem, TaVPE3 was weakly expressed at 12 $\mathrm{h}$ after $\mathrm{NaCl}$ treatment. In SA treatment, TaVPE3 was expressed within a short time. Expression level of TaVPE3 was very low in tissues comparing with other VPEs. TaVPE4 transcripts accumulation was kept in steady state than other TaVPEs. Signal strength of TaVPE4 was higher than other TaVPEs. However, TaVPE4 transcripts showed most variable expression patterns. In many cases, TaVPE4 was down-regulated under phytohormone-and stress-treated conditions. Increased transcripts accumulation of TaVPE4 was observed in each tissue during $\mathrm{NaCl}$ treatment. However, directly after $\mathrm{NaCl}$ treatment, TaVPE4 expression level was rapidly decreased in stem. After rapidly decrease, transcription level of TaVPE4 was gradually increased. TaVPE4 expression pattern in stem after $\mathrm{NaCl}$ treatment can be observed in leaf during $\mathrm{H}_{2} \mathrm{O}_{2}$ treatment. 
(A)
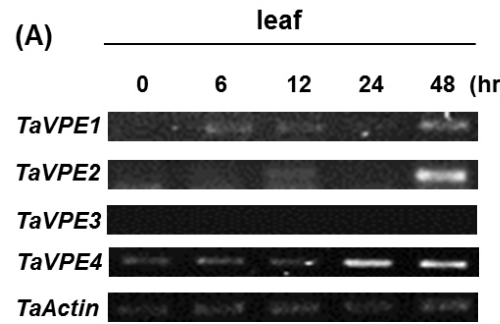

(B)

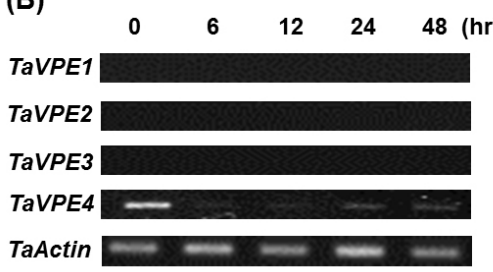

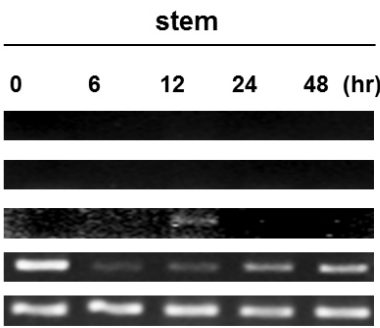
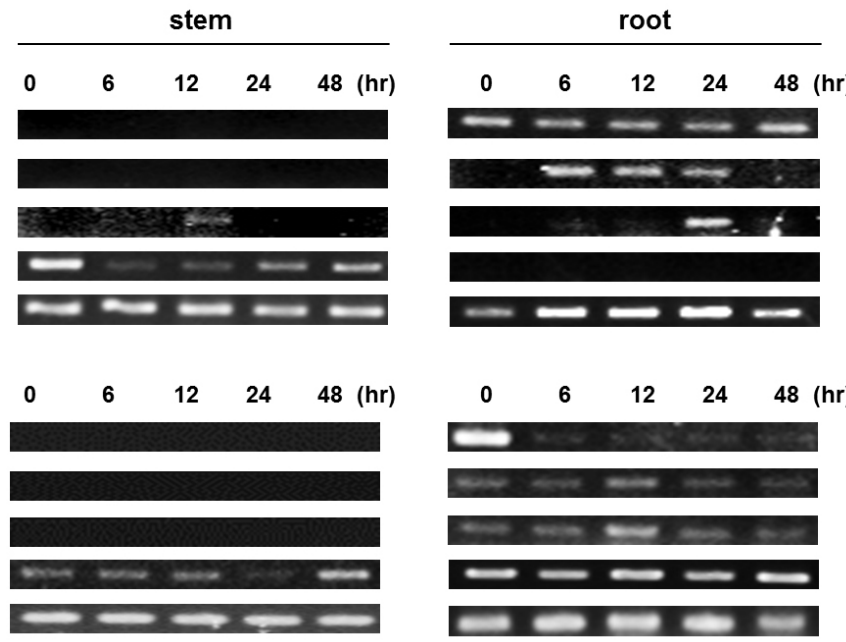

Fig. 4. Expression profiles of TaVPE genes. TaVPEs were differently expressed in each tissue under $\mathrm{NaCl}(\mathrm{A})$ and $\mathrm{H}_{2} \mathrm{O}_{2}$ (B) treatment. All samples were treated at secondary leaf fully expanded stage. $\left(\mathrm{NaCl}: 250 \mathrm{mM}, \mathrm{H}_{2} \mathrm{O}_{2}: 100 \mathrm{mM}\right)$.

(A)

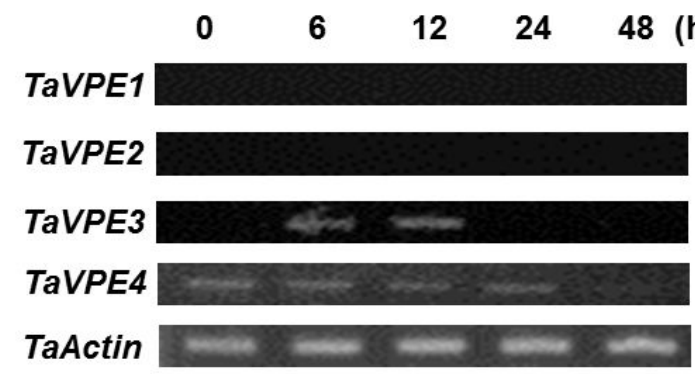

(C)

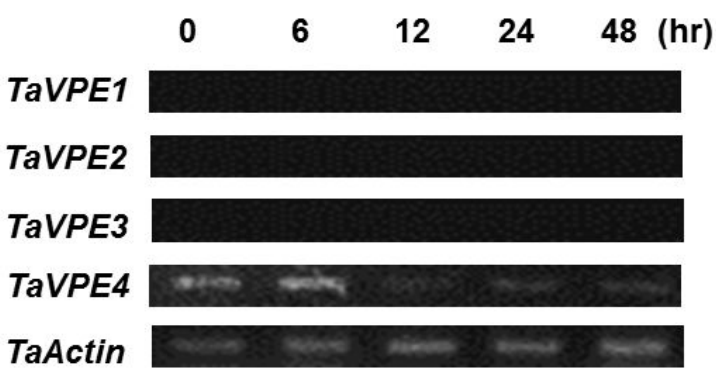

(B)

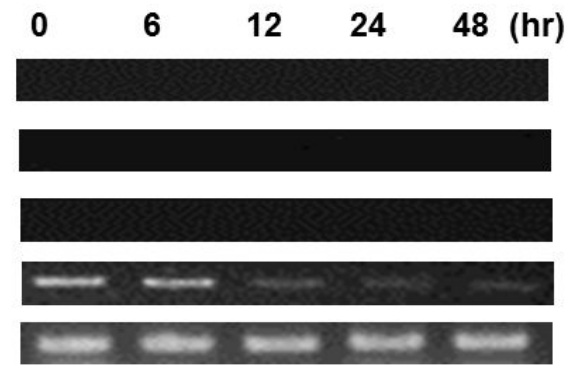

(D)

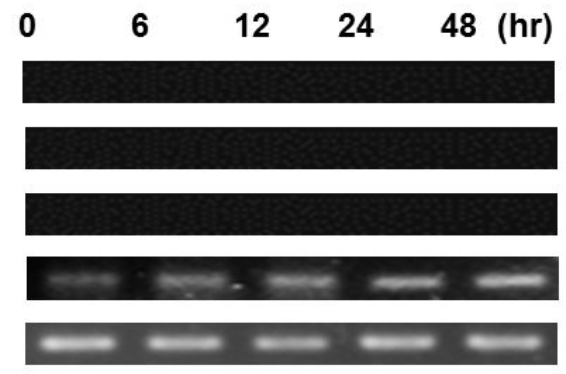

Fig. 5. Transcripts accumulation profiles of TaVPEs in wheat leaf expressed in responsive to (A) 5mM SA, (B) $25 \%$ PEG, (C) 100 $\mu \mathrm{M} \mathrm{GA}_{3}$, and (D) $100 \mu \mathrm{M} \mathrm{ABA}$ using RT-PCR analysis. All samples were treated at secondary leaf stage.

\section{Promoter Analysis}

To understand the mechanism associated with the regulation of TaVPE gene expression, the GenomeWalker strategy was used to isolate the TaVPE gene promoter region. The length of isolated promoter region was $846 \mathrm{bp}$ for TaVPE1, 2,048bp for TaVPE2, $843 \mathrm{bp}$ for TaVPE3 and
$537 \mathrm{bp}$ for TaVPE4.

Searches for putative cis-elements in promoter regions of the TaVPE genes were performed using plant promoter databases, PLACE Web Signal Scan (http://www.dna. affrc.go.jp/PLACE/signalscan.html) and plantCARE (http: //bioinformatics.psb.ugent.be/webtools/plantcare/html). 
cis-Elements related to transcriptional regulation by hormones and stresses were selected from a number of putative cis- elements and analyzed. Schematic diagrams of cis-elements of the TaVPEs promoter region are shown in Fig. 6.

The putative promoter regions of TaVPE1, 2 and 3 contained several common cis-elements such as CAAT box, CGTCA motif, G box, Skn-1, MBSI and LTR. TaVPE1, 2 and 3 promoter regions contained the cis-acting elements, Skn-1, that is required for endosperm expression. In the presence of Skn-1, transcripts accumulation of TaVPE1, 2 and 3 were detected in caryopsis during seed development stage. Instead of Skn-1, promoter region of TaVPE4 possessed GCN4 motif that involved in endosperm expression. In spite of many light- and Methyl Jasmonate (MeJA)- related elements, we could not find relationship between these cis-element and VPE. Wheat seedlings were not treated with dark condition and MeJA application. In case of TaVPE2, correlations were detected between the cis-elements found by plantCARE and PLACE and expression pattern of VPE2. The presence of the TC-rich motif corresponded to transcripts accumulation of TaVPE2 in leaf and root under $\mathrm{NaCl}$ and $\mathrm{H}_{2} \mathrm{O}_{2}$ treated condition.
PEG treatment induced at least 2.0-fold TaVPE2 transcript accumulation as indicated by results of RT-PCR. Many other cis-elements were found in the TaVPE2 promoter region, but few responses to the corresponding stress treatments were observed.

\section{DISCUSSION}

The wheat cv. Geumgangmill has good characteristics such as early maturity and protein quality, providing a good source for wheat flour in South Korea (http://oneclick. rda.go.kr/htmlfile/A0108050302/A010805030215.html; Rural Development Administration, Suwon, Korea). We isolated the 3 novel genes from wheat Geumgangmill that had high sequence homologies and determined as TaVPE genes. A number of VPEs have subfamily genes in a single plant species (Gruis et al. 2004; Zakharov et al. 2004). In case of wheat, isolation of TaVPE1, registered in the NCBI, and 3 novel wheat VPEs, designated TaVPE2, 3 and 4, were isolated in this study.

In silico analysis of the deduced amino acids sequences of TaVPE genes and VPEs of other plants showed that they
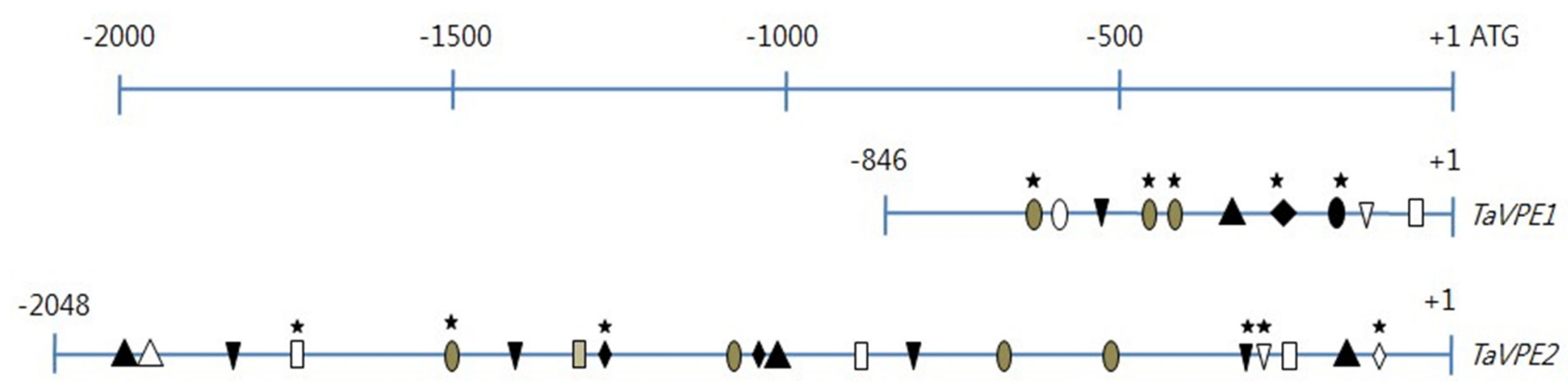

\footnotetext{
$\triangle$ WUN motif : wound responsive elements

ABSI : MYB binding site involved in flavono d biosynthetic genes regulation

口. Skn-1 : cis-acting regulatory element requir ed for endosperm expression

- ARE : cis-acting regulatory element essent al for the anaerobic induction

$\triangle$ AS2 box : involved in shoot-specific expres sion and light responsive

- TC-rich repeat : cis-acting element involve $d$ in defense and stress responsiveness
}

Fig. 6. Schematic comparisons of the cis-elements of the TaVPEs promoter regions. 
possessed five highly conserved domains, Casein kinase II phosphorylation site, N-myristoylation site, N-glycosylation site, cAMP- and cGMP- dependent protein kinase phosphorylation site and protein kinase $\mathrm{C}$ phosphorylation site. These conserved domains are present in other plant VPE such as Arabidopsis. The absence of cAMP- and cGAMPdependent protein kinase phosphorylation site in barley NP1, resulted to an incomplete sequence (Linnestad et al. 1998). Casein kinase II, protein kinase C, cAMP- and cGMP- dependent protein kinase play a key role in the control of phosphorylation in plant (Vandromme et al. 1996). Many enzymes are switched "on" or "off" by phosphorylation and dephosphorylation (Barford et al. 1998). It seems that these domains contributed to the activation of VPE. It was reported that inactivated VPE by caspase-1 inhibitor was associate with inhibition of HR (Hatsugai et al. 2004). Activated VPE exhibited typical HR as a response to pathogen (Hatsugai et al. 2004).

Kernel generally can be divided into two types of tissues, caryopsis and pericarp. The results of semi-quantitative RT-PCR suggested that expression of TaVPEs was observed in caryopsis, whereas only TaVPE4 gene was expressed in pericarp during seed development (Fig. 3). Wheat grain filling lasts for about twenty days after fertilization. Expression of TaVPE3 gene was detected in seed development stage and peaked at 10 DAF. Contrary to other TaVPEs, TaVPE3 gene was not expressed at 22 DAF. This expression pattern of TaVPE 3 is similar to transcripts accumulation of barley NP1 (Linnestad et al. 1998). TaVPE1 and TaVPE3 exhibited a slightly increased expression pattern in caryopsis during seed development stage whereas expression levels of TaVPE4 were kept at steady-state. Furthermore, TaVPE1 and TaVPE3 were expressed in leaf at later stage of seed development.

Satoru Nakaune et al (2005) has suggested that plant VPE can be divide into three types, vegetative type, seed type and uncharacterized (novel) type by their functional characteristics, expression pattern and sequence homology (Fig. 2). TaVPE1, 2, 3 and 4 belong to the seed type VPE group in phylogenetic grouping (A in Fig. 2). Seed type VPEs were reported that they are responsible for seed storage protein maturation. Studies using Arabidopsis mutant showed that VPE mutant plant could not produce matured seed storage protein and have only protein precursors (Gruis et al. 2004). Expression pattern of seed type VPE was mainly concentrated in seed development stage and early germination stage (Kinoshita et al. 1999). TaVPEs were also mainly expressed in seed development stage.

Many plant genes are up- or down-regulated by a various growth hormones during plant development (Kende and Zeevaart 1997). ABA plays regulatory roles in the plants seed and bud dormancy and responses to various stress conditions (Kende and Zeevaart 1997). GAs are plant hormones that regulate growth and influence various development processes, including stem elongation, germination, dormancy, flowering, enzyme induction and senescence (Kende and Zeevaart 1997). In ABA and $\mathrm{GA}_{3}$ treatment, only TaVPE4 exhibited a slightly decreased expression pattern. Other VPEs were not expressed in these phytohormones. SA is found in plants with roles in plant growth and development, photosynthesis, and ion uptakes (Van Huijsduijnen et al. 1986). It also plays a role in the resistance to pathogens by inducing the production of pathogenesis-related proteins (Van Huijsduijnen et al. 1986). It was reported that vegetative type VPE of Arabidopsis, aVPE and $\gamma$ VPE were up-regulated under SA treated condition (Kinoshita et al. 1999). Contrary to previous phytohormone treatments, TaVPE1 and TaVPE3 were expressed at $6 \mathrm{~h}$ after SA treatments. However, their transcripts accumulations vanished at $12 \mathrm{~h}$ after treatment.

Under stressed conditions, $\mathrm{pH}$ levels could be altered to acidic very easily (Yamada et al. 2005). These acidic conditions result in the reverse effects on viability of plant roots. The self-catalytic activation and maturation of VPEs occurs under the acidic condition (kuroyanagi et al. 2002). After $\mathrm{NaCl}$ and $\mathrm{H}_{2} \mathrm{O}_{2}$ treatment, TaVPEs were up-regulated in root. Especially, TaVPE4 is extensively expressed during these treatments. Transcription level of TaVPE4 was remarkably high during $24 \mathrm{~h}$ after $\mathrm{NaCl}$ treatment then its expression was decreased. Under $\mathrm{H}_{2} \mathrm{O}_{2}$ treatment condition, expression of TaVPE4 was significantly high in root which did not change across observation time. $\mathrm{NaCl}$ treatment showed a slight induction of TaVPE1 and TaVPE2 as shown in Fig. 4. At $48 \mathrm{~h}$ after treatment, significant visible transcripts of TaVPE1 and TaVPE2 were 
detected in leaf. It seems likely that VPE gene is very sensitive to salinity. Interestingly, all TaVPEs were significantly expressed in root after $\mathrm{H}_{2} \mathrm{O}_{2}$ treatment. It is thought that VPE genes of root are very sensitive to stress treatment because stress factors are directly absorbed through root.

Using the PlantCARE and the PLACE, it was revealed that promoter region of TaVPE1 and 2 contained a number of cis-acting elements involved in stress, phytohormone and light-responsiveness. A number of light responsive elements such as G box, GAG motif, SP1 and AS2 box were involved in their promoter sequence. The comparison of putative cis-elements taken from the promoter database in each TaVPE promoter region suggests that some identified sets of putative regulatory correlated with the responses of the TaVPE genes to the hormones and abiotic stresses. Promoter sequence of TaVPE2 contained two putative cis-elements, MBSI and ARE. Flavonoids are known to function in resistance to drought stress. They may protect the membrane against desiccation by interacting with lipid bilayer and function as protectants by scavenging ROS (Perez et al. 2002; Moore et al. 2005). MBSI is a cis-elements myb binding site involved in flavonoid biosynthetic genes regulation and ARE is known as a regulatory element essential for the anaerobic induction. The TaVPE2 and TaVPE4 expressed in the PEG treatments. However, some contradictions between the cis-elements and expression of TaVPEs imply the presence of unidentified cis-elements of promoter region.

TaVPE4 showed unique expression pattern compared with other TaVPEs. TaVPE4 belongs to seed-type VPE, but expression patterns in tissue-types and treatment conditions are different from seed-type VPE. TaVPE4 displayed tissue non-specific expression. It seems that promoter region of TaVPE4 would be different from those of other TaVPEs. VPEs have not been extensively studied under conditions with phytohormone and stresses. Thus, further expressional analysis of TaVPE genes and search of promoter region of TaVPE3 and 4 should be conducted to clarify the regulatory mechanism controlling the expression of these genes. Additional expression analysis under wound-, dark-, and MeJA-treated condition would provide the examination of relationship between cis-elements and transcripts accumulation of TaVPEs.

As undergoing senescence and stress, the secreted enzyme such as cysteine protease is changed and cells in specific tissues are ready to die (Kinoshita et al. 1999). VPEs are closely related to senescence and stressed-condition including disease-induced PCD in plants (Kinoshita et al. 1999). TaVPE1, TaVPE2 and TaVPE4 are strongly expressed in vegetative tissues such as senescing leaves. Especially, TaVPE4 showed the ordinary expression pattern of vegetative-type VPEs. Vegetative-type VPEs are expressed in vegetative tissue, such as stem and leaf. (Kinoshita et al. 1995a; Zakharov and Muntz 2004). However, TaVPE4 is also expressed in caryopsis and is belong to the seed-type VPE group on phylogenetic grouping (Fig. 2). We speculate that the classification into vegetative- and seed- specific VPE according to gene expression patterns and sequence homologies could not be applied to TaVPEs.

In this study, we isolated three novel VPEs, TaVPE2 and 3 and 4. TaVPEs including TaVPE1 differently expressed in separate tissues during seed development stage, stressor phytohormone- treatment. These results suggest that the TaVPEs have different roles during seed development and under stress- or phytohormone- treated condition. Expression analysis of tobacco legumain NtPB-1 and Arabidopsis $\delta$ VPE revealed that these genes displayed highly tissuespecific expression patterns (Zakharov and Muntz 2004; Nakaune et al. 2005).

\section{ACKNOWLEDGEMENTS}

This work was supported by the National Research Foundation of Korea (NRF) grant funded by the Korea government (MEST) (No. 2012K1A3A1A09028123). This research was also supported in part by National Agenda Programs for Agricultural R\&D of Rural Development Administration (PJ906953), Republic of Korea.

\section{REFERENCES}

Alonso JM and Granell A. 1995. A putative vacuolar processing protease is regulated by ethylene and also during fruit ripening in citrus fruit. Plant Physiol. 109:541-547. 
Barford D, Das AK and Egloff M-P. 1998. The structure and mechanism of protein phosphatases: insights onto catalysis and regulation. Annu. Rev. Bioph. Biom. 27:133-164.

Becker C, Shutov AD, Nong VH, Senyuk VI, Jung R, Horstmann C, Fischer J, Nielsen NC and Klaus M. 1995. Purification, cDNA cloning and characterization of proteinase B, an asparagine-specific endopeptidase from germinating vetch (Vicia sativa L.) seeds. Eur. J. Biochem. 228:456-462.

Bethke PC, Hillmer S and Jones RL. 1996. Isolation of intact protein storage vacuoles from barley aleurone (identification of aspartic and cysteine proteases). Plant Physiol. 110: 521-529.

Bonneau L, Ge Y, Drury GE and Gallois P. 2008. What happened to plant caspases? J. Exp. Bot. 59:491-499.

Cohen GM. 1997. Caspases: the executioners of apoptosis. Biochem. J. 326:1-16.

Fischer J, Becker C, Hillmer S, Horstmann C, Neubohn B, Schlereth A, Senyuk V, Shutov A and Müntz K. 2000. The families of papain- and legumain-like cysteine proteinases from embryonic axes and cotyledons of Vicia seeds: development patterns, intracellular localization and functions in globulin proteolysis. Plant Mol. Biol. 43:83-101.

Gruis D, Schulze J and Jung R. 2004. Storage protein accumulation in the absence of the vacuolar processing enzyme family of cysteine proteases. Plant Cell 16: 270-290.

Hara-Nishimura I, Hatsugai N, Nakaune S, Kuroyanagi M and Nishimura M. 2005. Vacuolar processing enzyme: an executor of plant cell death. Curr. Opin. Plant Biol. 8: 404-408.

Hara-Nishimura I, Inoue K and Nishimura M. 1991. A unique vacuolar processing enzyme responsible for conversion of several proprotein precursors into the mature forms. FEBS Lett. 294:89-93.

Hara-Nishimura I and Nishimura M. 1987. Proglobulin processing enzyme in vacuoles isolated from developing pumpkin cotyledons. Plant Physiol. 85:440-445.

Hara-Nishimura I, Nishimura M and Akazawa T. 1985. Biosynthesis and intracellular transport of $11 \mathrm{~S}$ globulin in developing pumpkin cotyledons. Plant Physiol. 77: 747-752.

Hatsugai N, Kuroyanagi M, Yamada K, Meshi T, Tsuda S, Kondo M, Nishimura M and Hara-Nishimura I. 2004. A plant vacuolar protease, VPE, mediates virus-induced hypersensitive cell death. Science 305:855-858.

Higo K, Ugawa Y, Iwamoto M and Korenaga T. 1999. Plant cis-acting regulatory DNA elements (PLACE) database: 1999. Nucl. Acids. Res. 27:297-300.

Kende H and Zeevarrt J. 1997. The five "Classical" plant hormones. Plant cell 22:1197-1210.
Kinoshita T, Yamada K, Hiraiwa N, Kondo M, Nishimura M and Hara-Nishimura I. 1999. Vacuolar processing enzyme is up-regulated in the lytic vacuoles of vegetative tissues during senescence and under various stressed conditions. Plant J. 19:43-53.

Kinoshita T, Nishimura M and Hara-Nishimura I. 1995a. Homologues of a vacuolar processing enzyme that are expressed in different organs in Arabidopsis thaliana. Plant Mol. Biol. 29:81-89.

Kinoshita T, Nishimura M and Hara-Nishimura I. 1995b. The sequence and expression of the $\gamma \mathrm{VPE}$ gene, one member of a family of three genes for vacuolar processing enzymes in Arabidopsis thaliana. Plant Cell Physiol. 36: 1555-1562.

Kiyosaki T, Asakura T, Matsumoto I, Tamura T, Terauchi K, Funaki J, Kuroda M, Misaka T and Abe K. 2009. Wheat cysteine proteases triticain $\alpha, \beta$ and $\gamma$ exhibit mutually distinct responses to gibberellin in germinating seeds. J. Plant Physiol. 166:101-106.

Kuroyanagi M, Nishimura M and Hara-Nishimura I. 2002. Activation of arabidopsis vacuolar processing enzyme by self-catalytic removal of an auto-inhibitory domain of the C-terminal propeptide. Plant Cell Physiol. 43:143-151.

Lee TG, Jang CS, Kim JY, Kim DS, Park JH, Kim DY and Seo YW. 2007. A Myb transcription factor (TaMyb1) from wheat roots is expressed during hypoxia: roles in response to the oxygen concentration in root environment and abiotic stresses. Physiol. Plantarum 129:375-385.

Lescot M, Dehais P, Thijs G, Marchal K, Moreau Y, Van de Peer Y, Rouze P and Rombauts S. 2002. PlantCARE, a database of plant cis-acting regulatory elements and a portal to tools for in silico analysis of promoter sequences. Nucl. Acids. Res. 30:325-327.

Linnestad C, Doan DNP, Brown RC, Lemmon BE, Meyer DJ, Jung R and Olsen O-A. 1998. Nucellain, a barley homolog of the dicot vacuolar-processing protease, is localized in nucellar cell walls. Plant Physiol. 118:1169-1180.

Martinez DE, Bartoli CG, Grbic V and Guiamet JJ. 2007. Vacuolar cysteine proteases of wheat (Triticum aestivum L.) are common to leaf senescence induced by different factors. J. Exp. Bot. 58:1099-1107.

Moore JP, Westall KL, Ravenscroft N, Farrant JM, Lindsey GG and Brandt WF. 2005. The predominant polyphenol in the leaves of the resurrection plant Myrothamnus flabellifolius, 3,4,5 tri-O-galloylquinic acid, protects membranes against desiccation and free radical-induced oxidation. Biochem. J. 385:301-308.

Müntz K. 1998. Deposition of storage proteins. Plant Mol. Biol. 38:77-99.

Nakaune S, Yamada K, Kondo M, Kato T, Tabata S, Nishimura M and Hara-Nishimura I. 2005. A vacuolar processing enzyme, $\delta \mathrm{VPE}$, is involved in seed coat 
formation at the early stage of seed development. Plant Cell 17:876-887.

Perez FJ, Villegas D and Mejia N. 2002. Ascorbic acid and flavonoid-peroxidase reaction as a detoxifying system of $\mathrm{H} 2 \mathrm{O} 2$ in grapevine leaves. Phytochemistry 60:573-580.

Shimada T, Hiraiwa N, Nishimura M and Hara-Nishimura I. 1994. Vacuolar processing enzyme of soybean that converts proproteins to the corresponding mature forms. Plant Cell Physiol. 35:713-718.

Van Huijsduijnen RAMH, Alblas SW, De Rijk RH and Bol JF. 1986. Induction by salicylic acid of pathogenesisrelated proteins and resistance to alfalfa mosaic virus infection in various plant species. J. Gen. Virol. 67: 2135-2143.

Vandromme M, Gauthier-Rouviere C, Lamb N and Fernandez A. 1996. Regulation of transcription factor localization: fine-tuning of gene expression. Trends Biochem. Sci. 21: 59-64.

Vaux DL and Korsmeyer SJ. 1999. Cell death in development. Cell 96: 245-254.

Wang Y, Zhu S, Liu S, Jiang L, Chen L, Ren Y, Han X, Liu F, Ji S, Liu X and Wan J. 2009. The vacuolar processing enzyme OsVPE1 is required for efficient glutelin processing in rice. Plant J. 58:606-617.

Woltering EJ, van der Bent A and Hoeberichts FA. 2002. Do plant caspases exist? Plant Physiol. 130:1764-1769.

Yamada K, Shimada T, Nishimura M and Hara-Nishimura I. 2005. A VPE family supporting various vacuolar functions in plants. Physiol. Plantarum 123:369-375.

Zakharov A and Muntz K. 2004. Seed legumains are expressed in stamens and vegetative legumains in seeds of Nicotiana tabacum L. J. Exp. Bot. 55:1593-1595. 
Appendix Table 1. The nucleotide-homology and expression patterns of ESTs from cDNA library expressed during 16 and 18 day after fertilization in wheat.

\begin{tabular}{|c|c|c|c|c|}
\hline No. & accession No. & function & E-value & Organism \\
\hline 1 & XM_003572974.1 & unknown & 0 & Triticum aestivum \\
\hline 3 & XM_003572368 & $\begin{array}{l}\text { fatty acid beta-oxidation multifunctional } \\
\text { protein-like }\end{array}$ & 0 & Brachypodium distachyon \\
\hline 4 & AK335059.1 & unknown & 0 & Triticum aestivum \\
\hline 6 & AJ438611.1 & nucleosome assembly protein 1 & 0 & Oryza sativa \\
\hline 7 & XM_003575523.1 & ethylene-insensitive protein 2-like & 0 & Brachypodium distachyon \\
\hline 8 & XM_003560684 & LRR receptor-like serine/threonine-protein kinase & 0 & Brachypodium distachyon \\
\hline 13 & XM_003577452.1 & Xaa-Pro aminopeptidase P-like & 0 & Brachypodium distachyon \\
\hline 16 & XM_003557695.1 & nucleoredoxin 1-2-like & 0 & Brachypodium distachyon \\
\hline 17 & GAJL01224176.1 & unknown & 0 & Triticum aestivum \\
\hline 23 & XM_003567746.1 & receptor-like protein kinase & 0 & Brachypodium distachyon \\
\hline 24 & AB029888.1 & sucrose 1-fructosytransferase & 0 & Triticum aestivum \\
\hline 27 & GAJL01276045 & unknown & 0 & Triticum aestivum \\
\hline 33 & GAJL01254795.1 & unknown & 0 & Triticum aestivum \\
\hline 37 & M90077.1 & elongation factor 1 alpha-subunit (TEF1) & 0 & Triticum aestivum \\
\hline 39 & GAJL01262300.1 & unknown & 0 & Triticum aestivum \\
\hline 40 & AF327046.1 & 1-Cys peroxiredoxin (PER1) & 0 & Triticum aestivum \\
\hline 43 & XM_003559238.1 & DEAD-box ATP-dependent RNA helicase like & $1.00 \mathrm{E}-158$ & Brachypodium distachyon \\
\hline 51 & XM_003579618.1 & acetyl-coenzyme A synthetase-like & 0 & Brachypodium distachyon \\
\hline 52 & XM_003563516.1 & indole-3-acetic acid-induced protein & $4.00 \mathrm{E}-73$ & Brachypodium distachyon \\
\hline 53 & GAJL01272262 & unknown & 0 & Triticum aestivum \\
\hline 55 & AF543198.1 & phosphate transporter 6 & $0.00 \mathrm{E}+00$ & Hordeum vulgare \\
\hline 57 & M98254.1 & PSI-D subunit of photosystem I & 0 & Hordeum vulgare \\
\hline 58 & FN429985.1 & glyceraldehyde-3-phosphate dehydrogenase & $0.00 \mathrm{E}+00$ & Triticum aestivum \\
\hline 59 & EF682132.1 & vacuolar processing enzyme 1 (VPE 1) & 0 & Triticum aestivum \\
\hline 60 & XM_003562216.1 & 2-oxoglutarate dehydrogenase comple & & Brachypodium distachyon \\
\hline 62 & X94352.1 & catalase & 0 & Triticum aestivum \\
\hline 63 & GAJL01046966.1 & unknown & $1.00 \mathrm{E}-118$ & Triticum aestivum \\
\hline 64 & XM_003560068 & $\begin{array}{l}\text { oxygen-evolving enhancer protein } 3-1 \text {, } \\
\text { chloroplastic-like }\end{array}$ & 0 & Brachypodium distachyon \\
\hline 65 & XM_003558796.1 & cytochrome P450 86B1-like & 0 & Brachypodium distachyon \\
\hline 67 & NM_001155699.1 & BAX inhibitor motif-containing protein 4 & 0 & Zea may \\
\hline 68 & XM_003559284.1 & & 0 & Brachypodium distachyon \\
\hline 70 & XM_003581500.1 & cytochrome P450 704C1-like & 0 & Brachypodium distachyon \\
\hline 71 & XM_003573279.1 & lysine histidine transporter 1-like & 0 & Brachypodium distachyon \\
\hline 72 & M96940.1 & endo-1,3-beta-glucosidase (isoenzyme IV) & 0 & Hordeum vulgare \\
\hline 73 & XM_003564446.1 & serine/threonine-protein kinase like & 0 & Brachypodium distachyon \\
\hline 74 & GAJL01232596.1 & unknown & 0 & Triticum aestivum \\
\hline 79 & XM_003563826 & formate dehydrogenase 1 & $2.00 \mathrm{E}-160$ & Brachypodium distachyon \\
\hline 91 & GAJL01259873.1 & & 0 & Triticum aestivum \\
\hline 96 & AY057118.1 & WCOR413-like protein beta form & 0 & Triticum aestivum \\
\hline 95 & XM_003573173.1 & $\mathrm{ABC}$ transporter $\mathrm{F}$ family member 1-like & $0.00 \mathrm{E}+00$ & Brachypodium distachyon \\
\hline 97 & XM_003558923.1 & COP9 signalosome complex subunit & $2.00 \mathrm{E}-93$ & Brachypodium distachyon \\
\hline
\end{tabular}


Appendix Table 1. Continued.

\begin{tabular}{|c|c|c|c|c|}
\hline No. & accession No. & function & E-value & Organism \\
\hline 98 & AK330527.1 & unknown & 0 & Triticum aestivum \\
\hline 99 & AK333039.1 & unknown & 0 & Triticum aestivum \\
\hline 101 & GAJL01271751.1 & unknown & 0 & Triticum aestivum \\
\hline 107 & XM_003580747.1 & polyamine oxidase 4 -like & 0 & Brachypodium distachyon \\
\hline 110 & AK373155.1 & unknown & 0 & Hordeum vulgare \\
\hline 114 & XM_003567348.1 & THO complex subunit 2-like & 0 & Brachypodium distachyon \\
\hline 115 & GAJL01227155.1 & unknown & 0 & Triticum aestivum \\
\hline 117 & GAJL01275155.1 & unknown & 0 & Triticum aestivum \\
\hline 121 & M90077.1 & $\begin{array}{l}\text { translation elongation factor } 1 \text { alpha-subunit } \\
\text { (TEF1) }\end{array}$ & 0 & Triticum aestivum \\
\hline 124 & XM_003568881.1 & $\begin{array}{l}\text { serine/threonine-protein phosphatase } 2 \mathrm{~A} \\
\text { regulatory subunit B }\end{array}$ & 0 & Brachypodium distachyon \\
\hline 130 & XM_003572633.1 & cytochrome P450 86B1-like & 0 & Brachypodium distachyon \\
\hline 132 & GAJL01187384.1 & unknown & 0 & Triticum aestivum \\
\hline 133 & XM_003576973.1 & 40S ribosomal protein S19-like & $6.00 \mathrm{E}-151$ & Brachypodium distachyon \\
\hline 134 & AK330414.1 & unknown & 0 & Triticum aestivum \\
\hline 142 & AK359789.1 & unknown & 0 & Hordeum vulgare \\
\hline 143 & XM_003562590.1 & GTP-binding protein 1 & 0 & Brachypodium distachyon \\
\hline 144 & XM_003563994.1 & exosome complex component rrp4-lik & 0 & Brachypodium distachyon \\
\hline 147 & XM_003569220.1 & myosin-Va-like & 0 & Brachypodium distachyon \\
\hline 150 & XM_003574440.1 & gibberellin 3-beta-dioxygenase 1-like & 0 & Brachypodium distachyon \\
\hline 155 & XM_003573973.1 & 60 S ribosomal protein L21-2-like & 0 & Brachypodium distachyon \\
\hline 158 & XM_003576493.1 & disease resistance protein RGA2-like & $7.00 \mathrm{E}-171$ & Brachypodium distachyon \\
\hline 160 & XM_003560701.1 & alpha-glucan water dikinase & 0 & Brachypodium distachyon \\
\hline 161 & GAJL01275155.1 & unknown & 0 & Triticum aestivum \\
\hline 162 & GAJL01261874.1 & unknown & 0 & Triticum aestivum \\
\hline 164 & GAJL01263710.1 & unknown & 0 & Triticum aestivum \\
\hline 165 & XM_003570714.1 & chaperone protein $\mathrm{ClpB} 3$ & 0 & Brachypodium distachyon \\
\hline 170 & XM_003569551.1 & $\begin{array}{l}\text { phytochrome-associated serine/threonine } \\
\text { protein phosphatase 1-like }\end{array}$ & 0 & Brachypodium distachyon \\
\hline 172 & GAJL01239546.1 & unknown & 0 & Triticum aestivum \\
\hline 173 & XM_003578624.1 & monodehydroascorbate reductase-like & 0 & Brachypodium distachyon \\
\hline 174 & GAJL01174843.1 & unknown & $1.00 \mathrm{E}-173$ & Triticum aestivum \\
\hline 177 & XM_003563760.1 & T-complex protein 1 subunit gamma-like & 0 & Brachypodium distachyon \\
\hline 178 & GAJL01183894.1 & unknown & 0 & Triticum aestivum \\
\hline 180 & GAJL01226876.1 & unknown & 0 & Triticum aestivum \\
\hline
\end{tabular}

